The stronger absorption of the NN substance in the ultraviolet range is explained by its considerably higher content of aromatic amino acids $\mathbf{s}^{10,11,21}$.

We thank Professor R. W. JEANLOZ, Harvard University, for the infrared tracings. This investigation was supported by U.S. Public Health Service Research grant AI-0568I from the National Institute of Allergy and Infectious Diseases and Research grant GM-II985 from the National Institute of General Medical Science. The Immunochemistry Department is maintained by the Susan Rebecca Stone Fund.

Department of Biochemistry,

Anatoly Bezkorovainy

Presbyterian-St. Luke's Hospital, Chicago, Ill., and

Department of Immunochemistry Research,

GEORG F. SPRINGER*

Evanston Hospital Association, and Department of Microbiology, $\quad$ Kyoко Hoтta

Northwestern University, Evanston, Ill. (U.S.A.)

I K. Landsteiner and P. Levine, Proc. Soc. Exptl. Biol., 24 (1927) 94 r.

2 K. Landsteiner and P. Levine, $J$. Exptl. Med., 48 (1928) 73 I.

3 G. F. Springer And N. J. Ansell, Proc. Natl. Acad. Sci. U.S., 44 (1958) I82.

4 O. Mäkelä and K. Cantell, Ann. Med. Expil. Biol. Fenniae Helsinki, 36 (I958) 366.

5 T. Baranowski, E. Lisowska, A. Morawiecki, E. Romanowska and K. Strózecka, $A v c h$. Immunol. Terapii Doswiadczalnej, 7 (1959) I5, 759.

6 E. Klenk and G. Uhlenbruck, Z. Physiol. Chem., 3 I9 (I960) I5I.

7 A. Morawiecki, Biochim. Biophys. Acta, 83 (I964) 339.

8 G. F. Springer, in R. W. JeAnloz and E. A. Balazs, Immunochemistry in The Aminosugars, Vol. IIb, Academic Press, New York, London, 1965, pp. 267-336.

9 G. F. Springer and K. Hotta, Federation Proc., 22 (I963) $226 \mathrm{r}$.

io G. F. Springer, Blood-Group Substances, Chapter 7 , in I5th Mosbach Coll. German Soc. Physiol. Chem. I964, Springer-Verlag, Berlin, Heidelberg, New York, 1965.

i G. F. Springer and K. Hotta, Biochemistry, submitted for publication.

12 Y. Nagai and G. F. Springer, Federation Proc., 2 I (1962) 67 d.

13 G. F. Springer and K. Hotta, Abstr. 6th Internatl. Congr. Biochem., I I (I964) t 83 .

14 H. Schachman, S. P. Colowick and M. O. Kaplan, in Methods in Enzymology, Vol. 4, Academic Press, New York, London, I957, p. 32.

I 5 H. Svensson, Acta Chem. Scand., 5 (I95I) 72.

I6 A. Bezkorovainy and D. G. Doherty, Arch. Biochem. Biophys., 96 (I962) $49 \mathrm{I}$.

17 A. Bezkorovainy, Arch. Biochem. Biophys., iro (1965) 558.

i8 G. F. Springer, T. Takahashi, P. R. Desai and B. Kolecki, Biochemistry, 4 (rg65) 2099.

ig R. H. Kathan, K. J. Winzler and C. A. Johnson, J. Exptl. Med., i I3 (Ig6i) 37.

20 P. H. Whitehead, Biochem. J., 95 (I965) 8P.

2 I G. F. Springer, Proc. Xth Congr. Intematl. Soc. Blood Transf., Stockholm, I964, Karger, Basel, New York, 1965, p. 7 or.

Received September 28 th, r965

* To whom correspondence should be directed.

Biochim. Biophys. Acta, I15 (Ig66) 50I-504

BBA 23 I 94

\title{
Ultraviolet absorption of $\mathbf{N}$-glycosidic (lysine-sugar) linkages
}

The ultraviolet absorption spectra of natural glycoproteins incorporating peptide-sugar linkages of the glycosidic ether or of the amide type have not been reported to be different from those of carbohydrate-free proteins. However, those proteinsugar complexes incorporating carbohydrate bound $N$-glycosidically to the $\varepsilon$-amino group of lysine residues have been less studied. The introduction of sugars carrying 
active carbonyl groups into proteins by reaction with free amino groups (Maillard reactions) is accompanied by marked alteration in the physicochemical behaviour of the protein. Considerable modification of the ultraviolet absorption spectrum of the protein was found to be a characteristic feature.

For the initial steps in the Maillard reaction of proteins and aldoses to proceed, the open-chain non-hydrated aldehydo configuration of the sugar is essential. These open-chain sugars are generated from the ring structure in heated aqueous solution, giving rise to carbonyl absorption at $275 \mathrm{~m} \mu$ (refs. I, 2). In the presence of protein, the elevation of extinction at $275 \mathrm{~m} \mu$ is far less evident due to trapping of the aldehydo sugar and the formation of new chromophores.

Fig. I shows that the familiar protein curve suffers considerable distortion due to the superposition of new absorption peaks appearing in the course of the reaction with sugar. Extinction coefficients increase over the whole range of wavelengths, the percentage increase being especially marked in the region $300-400 \mathrm{~m} \mu$. Solutions of these modified proteins possess a brown colour.
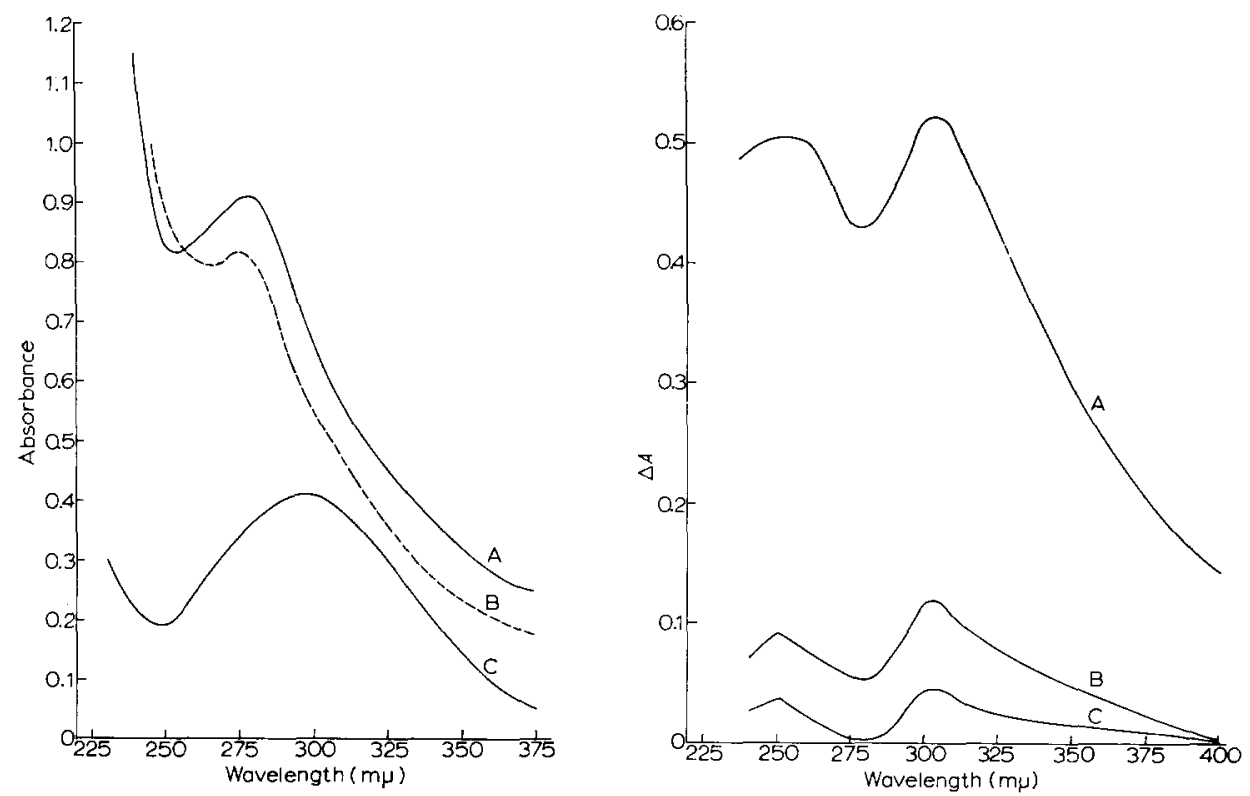

Fig. I. Absorption spectra of modified proteins. (A) Solution containing $\beta$-lactoglobulin (0.05\%) and $\mathrm{D}-\mathrm{xylose}(\mathrm{I} \%)$ in sterile phosphate buffer (o.o I M, pH 7.0) kept at $50^{\circ}$ for I $20 \mathrm{~h}$ and dialyzed; spectrum of freeze-dried protein $(0.05 \%)$ dissolved in the same buffer. (B) Solution containing crystalline human serum albumin $(0.05 \%)$ and $\mathrm{D}$-ribose $(\mathrm{I} \%)$ in the same buffer, kept at $50^{\circ}$ for $\mathrm{I}_{44} \mathrm{~h}$ and dialyzed; spectrum of freeze-dried protein $(0.05 \%)$ in phosphate buffer (pH 7.0 ) at room temperature. (C) Poly-L-lysine (Mann Research Labs., mean mol. wt., 75000), $0.05 \%$ in phosphate buffer o.or $\mathrm{M}(\mathrm{pH} 7.0)$ containing $\mathrm{I} \%$ D-ribose, kept at $50^{\circ}$ for $4 \mathrm{~h}$; corrected for controls.

Fig. 2. Difference spectra of modified proteins. (A) $\beta$-Lactoglobulin after $\mathrm{I} 2 \mathrm{O} \mathrm{h}$ treatment at $50^{\circ}$ with $\mathrm{D}$-xylose (I\%) in sterile phosphate buffer (o.o $\mathrm{M}, \mathrm{pH} 7.0$ ) and dialysis; spectrum of the freeze-dried product ( $0.05 \%$ in buffer) minus that of $\beta$-lactoglobulin control treated similarly but in the absence of xylose. (B) Same experiment using $\beta$-lactoglobulin $(0.05 \%)$ and $\mathrm{D}$-galactose (I \%) for $120 \mathrm{~h}$ at $50^{\circ}$. Spectrum of dialyzed and freeze-dried product minus that of protein control treated similarly but in the absence of galactose. (C) Same experiment using $\beta$-lactoglobulin and lactose; same concentrations, same period of time. 
Difference spectra relative to the control protein solutions reveal that the main peak is at $300-305 \mathrm{~m} \mu$ (Fig. 2). This is especially pronounced in the case of the nonabsorbing polymer poly-L-lysine which exhibits maximum absorption at $300 \mathrm{~m} \mu$ after its reaction with D-ribose. The spectrum of the modified polymer in Fig. I has been corrected for spectral alterations in the separate controls of sugar and polymer kept at $50^{\circ}$ under identical conditions; the dialyzed and freeze-dried product proved to be almost insoluble as a result of cross-linking (also observed by HANNAN AND $L_{L} A^{3}$ ).

The degree of modification of the ultraviolet spectrum depends on the nature of the sugar partner involved (i.e. on its reactivity, rate of ring opening, configuration, etc.), pentoses being more reactive than hexoses (Fig. 2).

The difference spectra for various sugar partners are congruent and reveal an impressive asymmetrical peak at $305 \mathrm{~m} \mu$; minor shoulders are observed at about 325 and $35^{\circ} \mathrm{m} \mu$, and extinction coefficients in the region $230-25^{\circ} \mathrm{m} \mu$ are markedly increased. Since $23^{\circ}, 3^{2} 5^{-}$and $35^{\circ}-\mathrm{m} \mu$ maxima are also observed in the spectra of heated sugar solutions containing no protein-due to the formation of the enol form of 3-deoxy-glycosuloses formed during thermal decomposition-it was concluded that the initial product of the Maillard reaction between protein and aldoses gives rise to a characteristic absorption maximum at $305 \mathrm{~m} \mu$. The shape of the difference curves and the position of the maxima being identical for various systems of proteins and different aldoses (down to triose), these results indicated that the chromophore responsible for absorption at $305 \mathrm{~m} \mu$ comprises a structural unit located near the site of attachment, i.e. involving the $\varepsilon$-amino group of lysine and the first two carbon atoms of the aldose.

Confirmation of this view was obtained by observing the spectra of reaction mixtures of aliphatic primary amines and simple aldoses $\left(C_{3}\right.$ to $\left.C_{6}\right)$. Fig. 3 records the spectra of mixtures of compounds of particular relevance to the problem of protein reactivity, viz, $n$-amylamine-ribose and $\varepsilon$-aminocaproic acid-ribose. Again, maxima at $300-305 \mathrm{~m} \mu$ rapidly appear in the spectrum, absorption at $305 \mathrm{~m} \mu$ being appreciable even before the development of a visible brown colour. This is in accordance

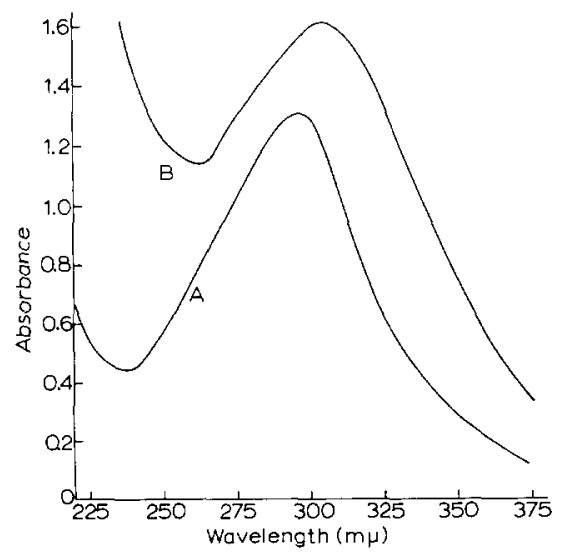

Fig. 3. Absorption spectrum of: (A) mixture of $\varepsilon$-aminocaproic acid (0.05\%) and D-ribose (I \%) (Io $\mathrm{ml}$ volume) kept at $5^{\circ}$ in phosphate buffer (o.or M, pH 7.o) for $48 \mathrm{~h}$; corrected for controls. (B) mixture of $n$-amylamine (0.01 $\mathrm{ml}$ ) and $\mathrm{D}$-ribose $(0.6 \%)(6 \mathrm{ml}$ volume) in phosphate buffer (o.OI $\mathrm{M}, \mathrm{pH} 7.0)$ kept at room temperature for $\mathrm{I} 20 \mathrm{~h}$; corrected for controls. 
with reports ${ }^{4}$ on substances isolated in the first stages of the Maillard reaction, which are colourless compounds. With the development of brown coloration, additional maxima appear at about 325 and $350 \mathrm{~m} \mu$.

In view of the mechanism of the Maillard reaction and the general absorption characteristics of $\alpha, \beta$-unsaturated carbonyl compounds it seems justifiable to conclude that the $305-\mathrm{m} \mu$ chromophore in the spectrum of protein after reaction with aldoses is the I,2-enol of the isomerization product arising from the initial amine-aldehyde condensation product by Amadori rearrangement. Further degradation of the enol form of this N-substituted I-amino-I-deoxy-2-ketose would lead to $2: 3$ enolization with the appearance of maxima in the region $325-350 \mathrm{~m} \mu$; the simultaneous occurrence of the $1: 2$-enol and $2: 3$-enediol forms (and possibly of their anions) in modified proteins would thus account for the brown colour of these proteins.

Part of this work has been supported by the Central Institute for Nutrition and Food Research T.N.O., Zeist, The Netherlands.

Department of Dermatology and Allergy,

L. BerRenS

Academic Hospital, The State University,

E. Bleumis $\mathrm{K}$

Utrecht (The Netherlants)

I E. Pacsu and L. A. Hiller, J. Am. Chem. Soc., 70 (1948) 523.

F. Petuely and N. Meixner, Chem. Ber., 86 (I953) I 255.

3 R. S. Hannan and C. H. Lea, Nature, I68 (I95I) 744.

4 K. Heyns and H. Paulsen, Ann. Chem., 622 (I959) I6o.

Received September 24th, 1965

Biochim. Biophys. Acta, I I 5 (I966) 504-507

BBA 23 I99

\section{Inhibition tests of plant agglutinins from Laburnum alpinum and Cytisus sessifolius with various sugars and sugar derivatives. Indication of the type of linkage in certain disaccharides}

It has long been known that extracts of certain plant seeds agglutinate human erythrocytes. However, it was not until Renkonen's discovery ${ }^{1}$ in 1948 that many plant agglutinins specific for human blood group antigen were described. At present, a number of plant agglutinins are being used instead of expensive absorbed immune serum for routine purposes such as determination of subgroups $A$ and $A B$, diagnosis of secretors and A,B,O-blood grouping. In I953, MORGAN AND WATkINS ${ }^{2}$ reported the inhibiting activity of simple sugars on the reaction between human erythrocytes and blood group specific plant agglutinins. This finding gave us a clue for testing the blood group specificity from a standpoint of chemical structure. As for the anti$\mathrm{H}(\mathrm{O})$ agglutinins from seeds of Laburnum alpinum and Cytisus sessifolius, KRÜPE ${ }^{3}$ found that the agglutination of human blood group $O$ erythrocytes by these agglutinins was inhibited by salicin, while the agglutinations with another group of anti-H(O) agglutinins, namely eel serum and extracts of seeds of Lotus tetragonolobus or Ulex europeus, were found to be inhibited by L-fucose $e^{2,4}$, one of the common constituents of blood group substances. Recently, Watkins AND MoRGAN ${ }^{5}$ reported the 